\title{
Numerical model for pollutant dispersion in the Dumai estuary
}

\author{
Mubarak ${ }^{1}$ Sigit Sutikno,"*, Rena Dian Merian ${ }^{3}$ \\ ${ }^{1}$ Marine Science Department Faculty of Fisheries, University of Riau, 28293 Pekanbaru, Indonesia \\ ${ }^{2}$ Civil Engineering Department University of Riau, 28293 Pekanbaru, Indonesia \\ ${ }^{3}$ Environmental Science Department Post Graduate Program, University of Riau, 28293 Pekanbaru, Indonesia
}

\begin{abstract}
The development of industry and the urban population in Dumai city potentially increases the amount of domestic sewage into the Dumai River, which is gradually deposited in the Dumai estuary. This condition has an impact on the environment and public health because of the higher concentration of pollutants. Knowing the dispersion of pollutants is very important in order to manage and monitor the water quality in the Dumai estuary. This research simulated a numerical model that was developed using MIKE 21 to study pollutant dispersion in the Dumai estuary as an impact of domestic sewage from Dumai city. Three important parameters of pollutants were discussed in this study, such as ammonia, nitrates and nitrites. The data used for modeling included winds, tides, bathymetry, and the pollutant concentration. The result of the numerical simulations shows that the concentration of all pollutant parameters tends to increase in the Dumai estuary. The concentration of ammonia, nitrates, and nitrites increase to $0.4 \mathrm{mg} / \mathrm{L}, 0.15 \mathrm{mg} / \mathrm{L}$, and $0.14 \mathrm{mg} / \mathrm{L}$ respectively. Those concentrations exceed the standard maximum value that has been appointed by Indonesian regulations. It means the domestic sewage from Dumai city should be treated before it is discharged into the river.
\end{abstract}

\section{Introduction}

Dumai is the capital city in the Riau province on the island of Sumatera, Indonesia, which has an area of $1,727.38 \mathrm{~km}^{2}$ and had 280,129 inhabitants in 2014 [1]. As a result of the geographic location, Dumai has an important role in transport and trade both regionally and internationally, especially to Malaysia. Dumai also has an important role in the oil industry both for fuel and palm oil, which generates economic activity. The development of industry and the urban population of Dumai city potentially increase the amount of domestic sewage into the Dumai River, which is gradually deposited in the Dumai estuary. This condition has an impact on the environment and public health because of the higher concentration of pollutants. Knowing the dispersion of pollutants is very important in order to manage and monitor the water quality in the Dumai estuary.

The water quality in the river should be managed and monitored periodically in the whole river, from upstream to downstream. This can be done by collecting and analyzing the time histories of water quality data of the river. By collecting and analyzing of those data, the pattern of pollutant dispersion and the potential impact because of the pollutants can be predicted. Those historical data can be obtained through continuous monitoring activities. However, these activities require substantial funds and long-term observation. To overcome these problems, an alternative solution can be found with a numerical model simulation. Numerical model simulation can be used to predict the dispersion of pollutants for various scenarios of input data both in the current conditions and in the future conditions. Numerical model simulation provides a powerful and unique capability for engineering studies of complex problems occurring under realistic field conditions [2].

To study pollutant dispersion in the Dumai estuary as impact of domestic sewage from Dumai city, this research simulated a numerical model which was developed using MIKE 21 as in many similar studies [3], [4], [5], [6]. MIKE 21 is a model frequently used for coastal simulations, developed by DHI (Danish Hydraulic Institute Environment). The hydrodynamic module in MIKE 21 is a general numerical modeling system for the simulation of water levels and flows in estuaries, bays and coastal areas; it simulates unsteady two-dimensional flows in one layer.

\section{Methods}

\subsection{Study area}

This study focused on the Dumai estuary, which is located in Dumai Kota sub-district, Dumai city, Riau province. Dumai is a capital city in Riau province on the

\footnotetext{
*Corresponding author: ssutiknoyk@yahoo.com
} 
island of Sumatera, Indonesia as shown in Figure1. Dumai River is the main river that flows through the city and disembogues into the Rupat Straits. The river potentially brings many kinds of pollutants as a result of human activity in Dumai city.

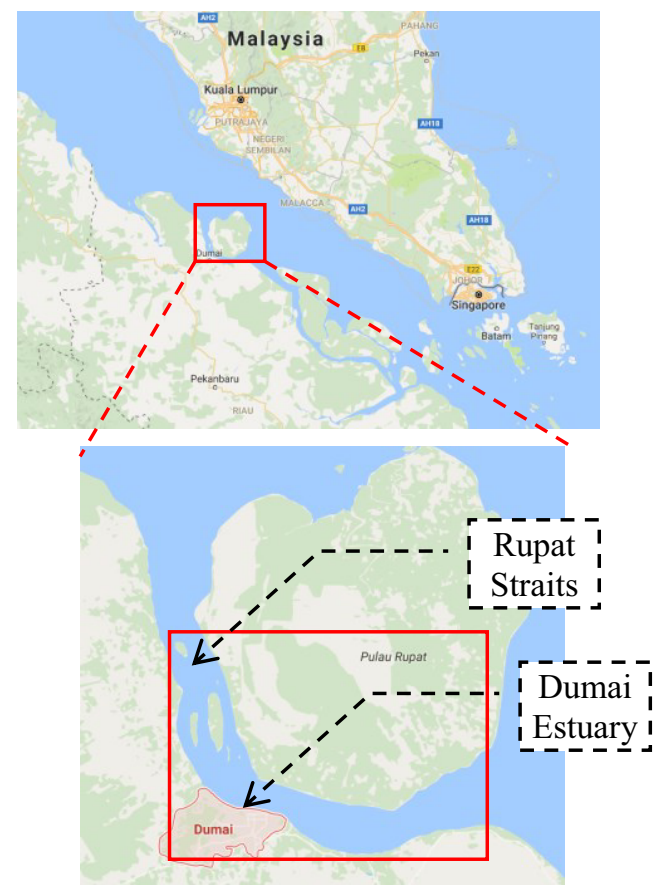

Fig. 1. Study area of this research.

\subsection{Field survey}

For numerical calibration, this research needs ground measurement data. The field survey was conducted on May 13-16, 2016 to get the measurement data. The position of sampling points was decided based on the purposive sampling method. The coordinate position of sampling points in the research area was used to guide the certain location for data measurements as shown in Figure 2.

Water quality parameters, which were measured in the sampling points, are ammonia, nitrates, and nitrites. Ammonia, a chemical compound with the formula $\mathrm{NH}_{3}$, is a chemical parameter to determine the quality of water based on the Ministry of Environment's regulation No. 51,2004 . These compounds are usually found in the form of gas with a pungent odor that is characteristically called 'ammonia odor'. Ammonia is a nitrogen compound that is important and widely produced. Although ammonia has contributed significantly to the presence of nutrients in the earth, ammonia itself is a caustic compound that can damage health. Ammonia is toxic to fish and is also produced from the secretions or feces of fish.

Nitrate is a polyatomic ion with the molecular formula $\mathrm{NO}_{3}$ that, in freshwater or estuarine systems close to land can reach high levels that can potentially cause the death of fish. While nitrate is much less toxic than ammonia, levels over $30 \mathrm{ppm}$ of nitrate can inhibit growth, impair the immune system and cause stress in some aquatic species [7]. However, in light of inherent problems with past protocols on acute nitrate toxicity experiments, the extent of nitrate toxicity has been the subject of recent debates. The nitrite ion, which has the chemical formula $\mathrm{NO}_{2}$ is the toxic by-product of the nitrifying bacteria (Nitrospira) in a filter or substrate consuming ammonia. It is only mildly less toxic than ammonia but it still can kill aquatic animals if its levels get too high.

These parameters were measured at a distance of 25 $\mathrm{m}, 50 \mathrm{~m}$, and $100 \mathrm{~m}$ from the river mouth towards the Rupat Straits and were performed at high tide and low tide. The analysis of ammonia, nitrate and nitrite concentrations were conducted at the Marine Chemistry Laboratory, Faculty of Fisheries and Marine Sciences, University of Riau. The method and working principle refers to the Indonesian National Standard (SNI) 066989.30-2005, SNI 06-6989.9-2004, and SNI 06-24801991 for the measurement of ammonia, nitrites, and nitrates respectively.

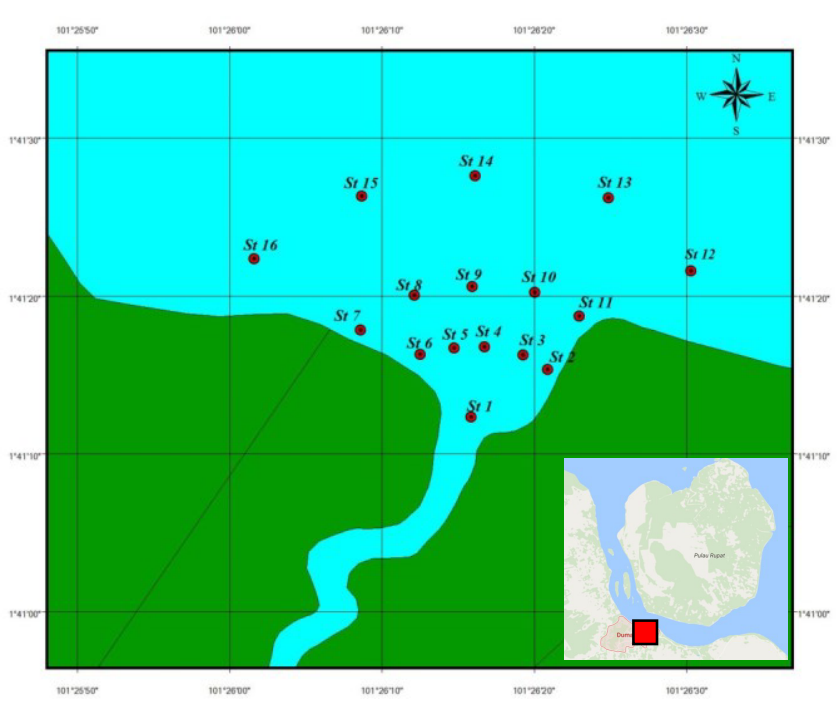

Fig. 2. Sampling points for field survey.

\subsection{Numerical model}

With the increase in computational technology, many numerical models and software programs have been developed for various engineering practices. Numerical modeling has been used extensively in industries for both forward problems and inverse problems. Forward problems include simulation of space shuttle flight, ground water flow, material strength, earthquakes, and molecular and medication formulae studies. Inverse problems consist of non-destructive evaluation (NDE), tomography, source location, image processing, and structure deformation during loading tests.

The hydrodynamics are represented through the shallow water equations, which must be solved numerically [6], [8]. Software Mike 21, from DHI Water 
\& Environment, was used. The model domain was the whole area of the Rupat Straits, as shown in Figure 3.

A non-structured triangular elements grid was built, with a higher density of nodes within the problem zone. The spatial step ranged from about 100 to $2000 \mathrm{~m}$, for a total of about 75,000 nodes. The bathymetry of the sea bottom was built based on data reported in the nautical charts of the Hydro-Oceanographic Agency, Indonesian Army as shown in Figure 4. The bathymetry of Rupat Straits shows that the depths ranging from 2.5 to $35 \mathrm{~m}$. Regional marine waters that have a depth of about $5 \mathrm{~m}$ are usually not so far from the shoreline. The depth of the waters around the Strait Rupat troughs is relatively steep. The depth of the waters of east, south and north Rupat range from 10 to $20 \mathrm{~m}$, while the depth of the waters in the northeast and east range from 30 to $35 \mathrm{~m}$.

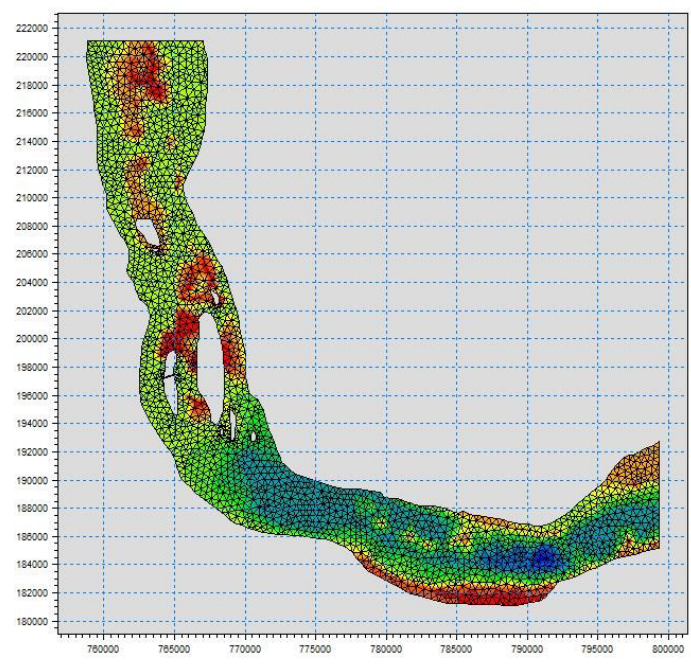

Fig. 3. Domain area of the numerical model.

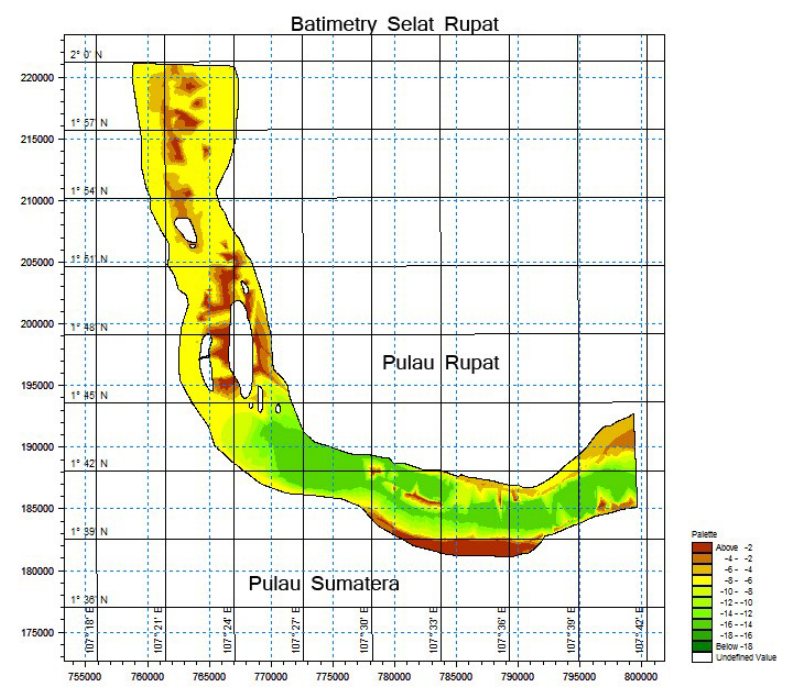

Fig. 4. Bathymetry map of the research area.

The numerical model is based on the mass conservation of pollutants, that leads to a system of $2 \mathrm{D}$ advection-diffusion equations, including source (or sink) terms to represent transformation processes through which coupling among them exists. This system must also be solved numerically. In order to achieve this,
Mike 21 software was used. Three water quality parameters modeled were ammonia $\left(\mathrm{NH}_{3}\right)$, nitrates $\left(\mathrm{NO}_{3}\right)$, and nitrites $\left(\mathrm{NO}_{2}\right)$.

\subsection{Model calibration}

Two parameters were calibrated, which dominantly affect the hydrodynamics of the estuary, such as roughness coefficient of the Manning value (n) and viscosity turbulent or eddy viscosity (c). Those parameters were adjusted so the predicted tide was as close as possible to the measured tide [9]. Figure 5 shows the comparison between the predicted tide and the measured tide as a result of the calibration process. The mean relative error (MRE) for this condition is $34.02 \%$, and the Manning value and eddy viscosity are $32 \mathrm{~m}^{(1 / 3)} / \mathrm{s}$ and $0.28 \mathrm{~m}^{2} / \mathrm{s}$ respectively.

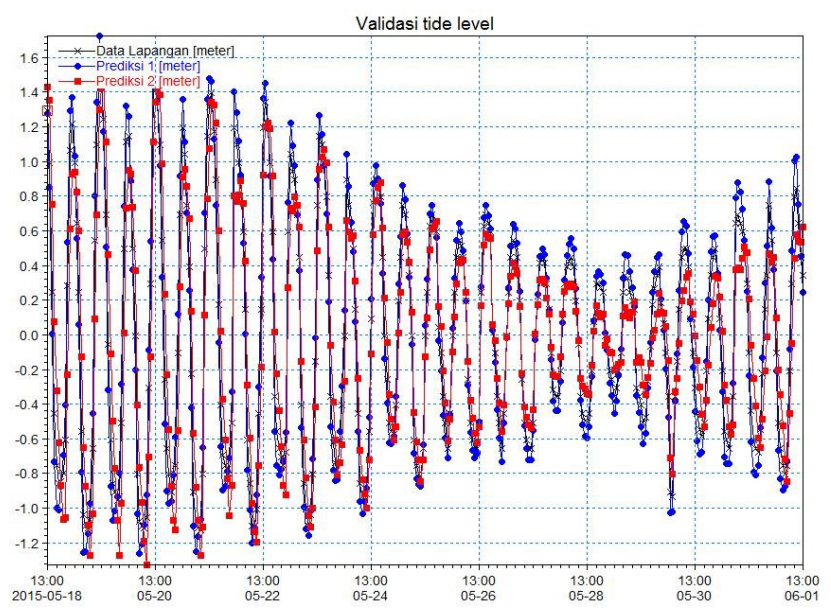

Fig. 5. Comparison between predicted tide and measured tide for the calibration process.

\section{Results and discussions}

\subsection{Currents pattern of the rupat strait}

The currents pattern in the Dumai estuary is greatly affected by the tide phenomenon because during a low tide the sea water is quickly attracted to the ocean causing sea levels to drop dramatically and quickly. Otherwise, in the case of high tide, sea water will get into the estuary area and bathe low-lying areas. This phenomenon has formed a pattern of movement of currents in the Dumai estuary. It means the tidal conditions are a major factor in the movement of aquatic pollutants.

The Dumai estuary experiences semidiurnal tide, which means it has two high tides and two low tides each day. The two high and the two low tides are nearly the same height. Currents in the Dumai estuary are generated by the long-wave movement of tides that creep from the Malacca Strait. During high tide, the current travels from the north to the south and east, as shown in Figure 6. In contrast, during low tide, the current moves from the east to the west, turns north, and exits in the 
Malacca Strait, as shown in Figure 7. The magnitude of the current velocity is generally in the range of 0.2 to $0.45 \mathrm{~m} / \mathrm{s}$.

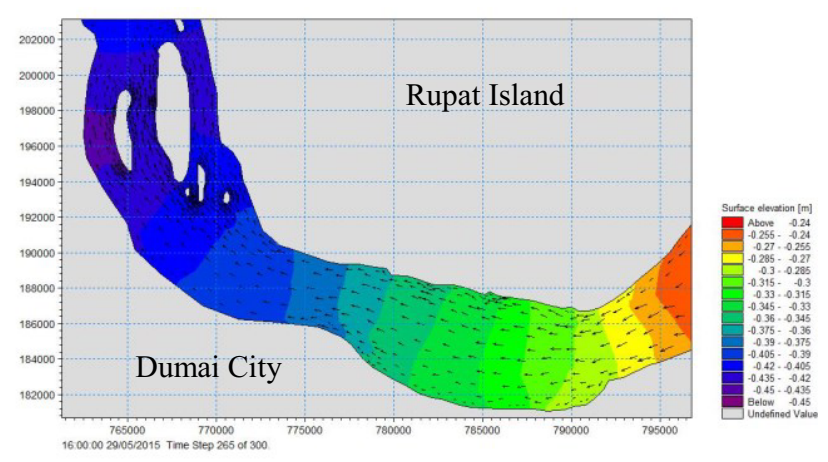

Fig. 6. The current pattern of Rupat Strait during low tide.

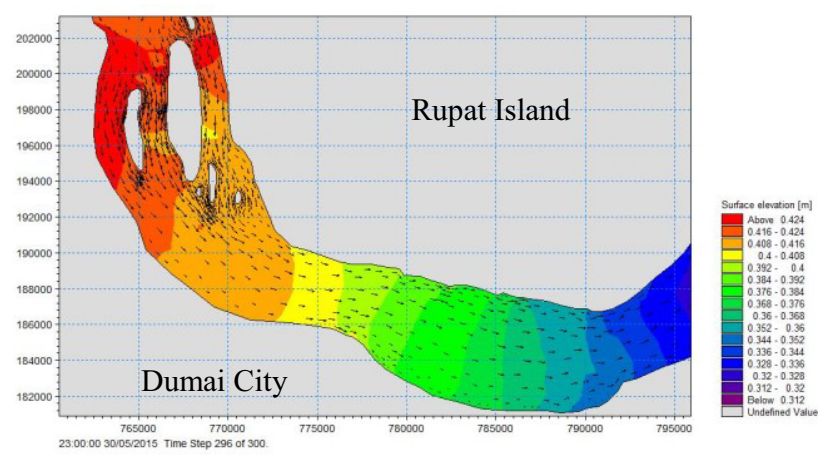

Fig. 7. The current pattern of Rupat Strait during high tide.

\subsection{The dispersion of pollutant}

The results of the current pattern from simulation of the hydrodynamic model were used as the basis for the simulation of the pollutant transport model. The simulations were carried out by the data input concentration of each pollutant that flows from Dumai River. The concentration of ammonia, nitrate, and nitrite in the river are $0.912 \mathrm{mg} / \mathrm{L}, 0.352 \mathrm{mg} / \mathrm{L}$, and 0.115 $\mathrm{mg} / \mathrm{L}$, respectively. Meanwhile, the concentrations of ammonia, nitrates, and nitrites in the waters of the Rupat Strait are $0.433 \mathrm{mg} / \mathrm{L}, 0.096 \mathrm{mg} / \mathrm{L}$, and $0.103 \mathrm{mg} / \mathrm{L}$, respectively. Those concentrations were used as the initial condition value for computation.

\subsubsection{Ammonia dispersion}

The distribution of ammonia tends to spread to follow the movement of currents. During low tide, the ammonia dispersion spread to the northwest, as shown in Figure 8. On the other hand, during high tide, the ammonia dispersion spread to the southeast as shown in Figure 9. Because of the Dumai River which contains ammonia concentration of about $0.912 \mathrm{mg} / \mathrm{L}$, the concentration of ammonia around the estuary increases from $0.32 \mathrm{mg} / \mathrm{L}$ to $0.40 \mathrm{mg} / \mathrm{L}$ in the high tide and from $0,012 \mathrm{mg} / \mathrm{L}$ to $0.0135 \mathrm{mg} / \mathrm{L}$ in the low tide, as shown in Figure 8 and Figure 9, respectively. In the high tide condition, the concentrations exceed the standard of maximum values that have been appointed by Indonesian regulations $(0.30$ $\mathrm{mg} / \mathrm{L})$.

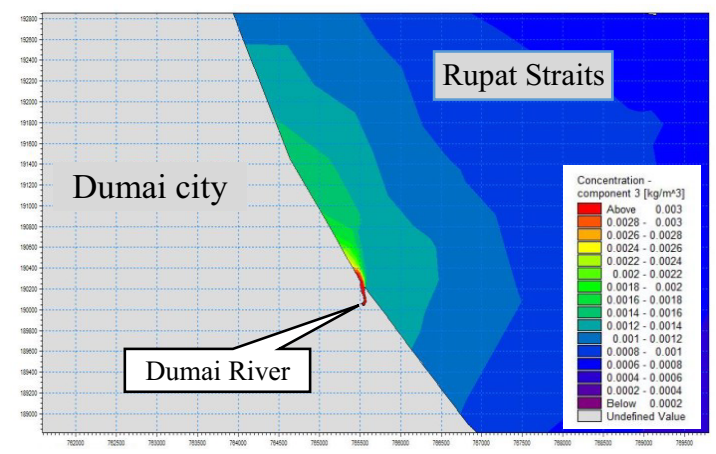

Fig. 8. Ammonia dispersion during low tide.

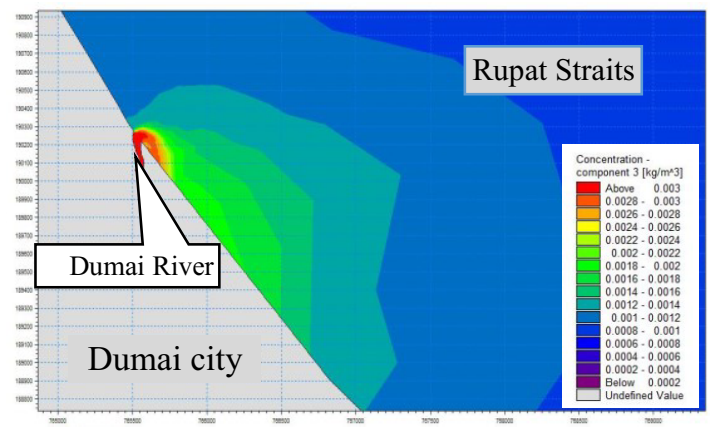

Fig. 9. Ammonia dispersion during high tide.

\subsubsection{Nitrate dispersion}

Similar with ammonia dispersion, the dispersion pattern of nitrates also tends to spread to follow the movement of currents but the rate of dispersion is smaller, as shown in Figure 10 and Figure 11. Nitrate pollutants originate from the Dumai River at a concentration of $0.352 \mathrm{mg} / \mathrm{L}$, thus increasing the nitrate concentration around the estuary from $0.105 \mathrm{mg} / \mathrm{L}$ to $0.15 \mathrm{mg} / \mathrm{L}$ during low tide and from $0,048 \mathrm{mg} / \mathrm{L}$ to $0.056 \mathrm{mg} / \mathrm{L}$ during high tide. The concentrations of nitrates exceed the standard maximum value that has been appointed by Indonesian regulations $(0.008 \mathrm{mg} / \mathrm{L})$ in both high and low tide conditions.

\subsubsection{Nitrite dispersion}

Nitrite is a form of nitrogen that is contained in water. Nitrogen in the form of nitrite is the form between nitrate and ammonia, both in the process of oxidation of ammonia to nitrate and in the reduction of nitrate to nitrite [10]. This is the reason why the nitrite content in water is very limited.

The concentration of nitrite tends to spread to follow the movement of currents. In the low tide conditions, the nitrite dispersion spreads to the northwest, as shown in Figure 12. In the high tide condition, the nitrite spreads to the southeast, as shown in Figure 13. Because of the Dumai River which contains nitrite concentration of 
about $0.115 \mathrm{mg} / \mathrm{L}$, the concentration of nitrite around the estuary increased from $0.1 \mathrm{mg} / \mathrm{L}$ to $0.14 \mathrm{mg} / \mathrm{L}$ in the high tide and from $0,01 \mathrm{mg} / \mathrm{L}$ to $0.012 \mathrm{mg} / \mathrm{L}$ in the low tide as shown in Figure 12 and Figure 13, respectively. The nitrite concentrations do not exceed the standard of maximum value that has been appointed by Indonesian regulations $(0.06 \mathrm{mg} / \mathrm{L})$ in both high and low tide conditions.

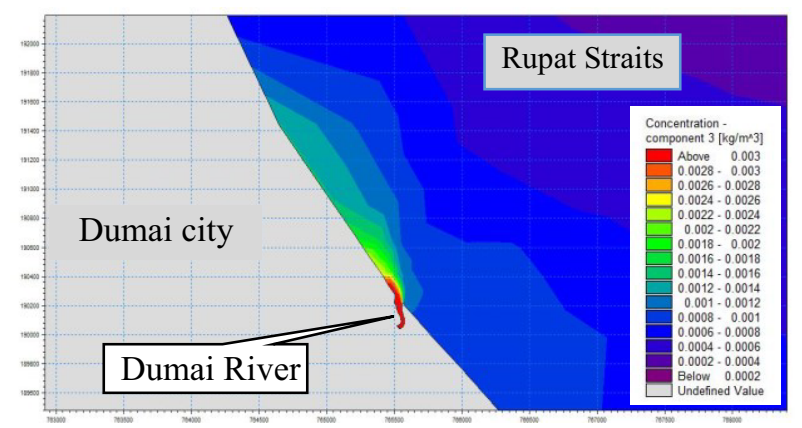

Fig. 10. Nitrate dispersion during low tide.

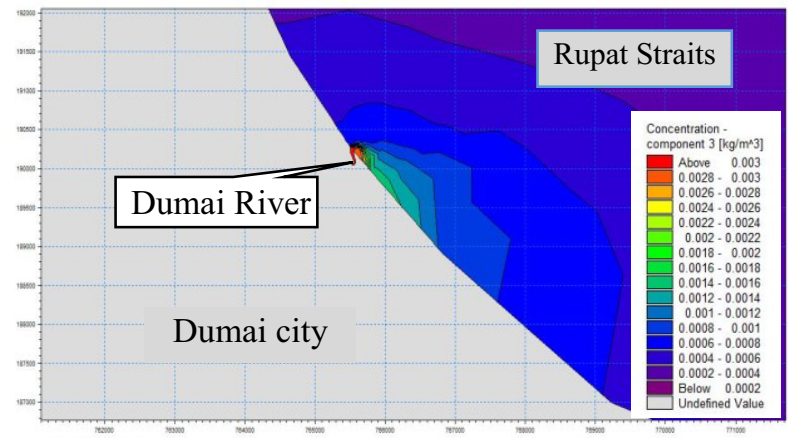

Fig. 11. Nitrate dispersion during high tide.

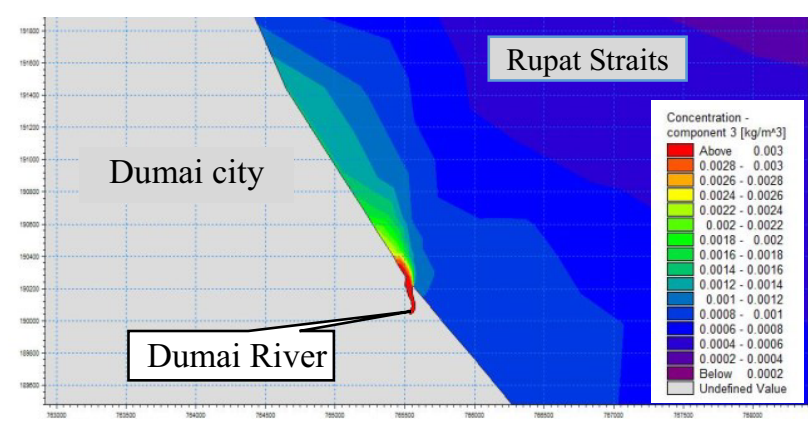

Fig. 12. Nitrite dispersion during low tide.

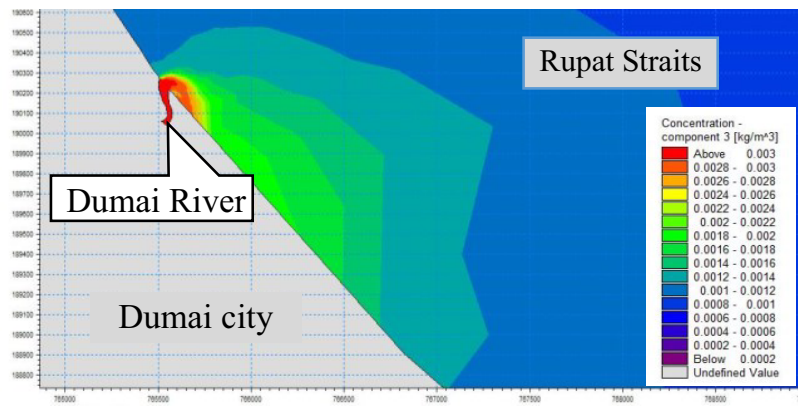

Fig. 13. Nitrite dispersion during high tide.

\section{Conclusions}

This study applied a numerical model to predict pollutant dispersion in the Dumai estuary using the MIKE 21 tool in order to manage and monitor water quality. The result of the numerical simulations showed that the concentration of all pollutant parameters tends to increase in the Dumai estuary. The concentration of ammonia, nitrates and nitrites increase to $0.4 \mathrm{mg} / \mathrm{L}, 0.15$ $\mathrm{mg} / \mathrm{L}$, and $0.14 \mathrm{mg} / \mathrm{L}$, respectively. Those concentrations exceed the standard of maximum value that has been appointed by Indonesian regulations. It means the domestic sewage from Dumai city should be treated urgently before discharged into the river.

The author would like to thank the Directorate General of Higher Education (DIKTI) - Ministry of Research, Technology and Higher Education for its research grants program.

\section{References}

1. Dumai Dalam Angka (Dumai in Figure) 2015, vol. 1. 2015.

2. S. Sutikno, K. Murakami, D. P. Handoyo, and M. Fauzi, "Calibration of Numerical Model for Shoreline Change Prediction Using Satellite Imagery Data," Makara J. Technol., vol. 19, no. 3, pp. 113-119, 2015.

3. a. N. Menendez, N. D. Badano, M. F. Lopolito, and M. Re, "Water quality assessment for a coastal zone through numerical modeling," $J$. Appl. Water Eng. Res., vol. 1, no. 1, pp. 8-16, 2013.

4. C. Paper, M. Ben, M. Politecnico, and M. M. Politecnico, "Numerical results of the pollutant spreading offshore Taranto," 2009, no. August 2016.

5. D. Vouk, G. Lončar, and D. Bekić, Tech. Gaz., vol. 6, pp. 255-262, 2010.

6. S. Davies, H. Mirfenderesk, R. Tomlinson, and S. Szylkarski, "Hydrodynamic, Water Quality and Sediment Transport Modeling of Estuarine and Coastal Waters on the Gold Coast Australia," J. Coast. Res., vol. 2009, no. 56, pp. 937-941, 2009.

7. N. Romano and C. Zeng, "Acute toxicity of sodium nitrate, potassium nitrate, and potassium chloride and their effects on the hemolymph composition and gill structure of early juvenile blue swimmer crabs(Portunus pelagicus Linnaeus, 1758) (Decapoda, Brachyura, Portunidae).," Environ. Toxicol. Chem., vol. 26, no. 9, pp. 1955-1962, 2007.

8. J. Jakeman, “ON NUMERICAL SOLUTIONS OF THE SHALLOW WATER WAVE EQUATIONS," 2006.

9. M. Abbaspour, a Javid, P. Moghimi, and K. Kayhan, "Modeling of thermal pollution in coastal area and its economical and 
environmental assessment," Int. J. Environ. Sci. Technol., vol. 2, no. 1, pp. 13-26, 2005.

10. M. K. Pigue, "Changes in Dissolved Oxygen, Ammonia, and Nitrate Levels in an Extended Aeration Wastewater Treatment Facility When Converting From Counter Current to Disc Diffuser Aeration," 2013. 